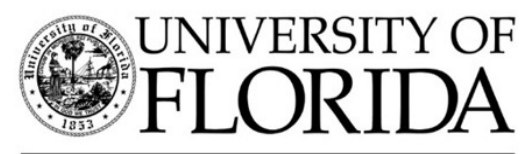

IFAS EXTENSION

\title{
Vida Saludable para Personas de Edad: Los Alimentos Pueden Afectar Sus Medicinas ${ }^{1}$
}

\section{Paulina Wittkowsky}

Los alimentos pueden alterar el efecto de los remedios que le receta su médico y de las medicinas que se despachan sin receta. Esto puede causar efectos no deseados. Si usted toma ciertas medicinas, debe evitar algunos alimentos.

\section{ALCOHOL}

Beber alcohol cuando usted está tomando ciertas medicinas puede ser muy peligroso.

Ejemplos de medicinas que no deben mezclarse con alcohol son el acetaminofén (como Tylenol ${ }^{\mathrm{TM}}$ ), los antihistamínicos (como Benadryl ${ }^{\mathrm{TM}}$ ) y el ibuprofén (como Motrin ${ }^{\mathrm{TM}}$ ).

\section{¡Siempre pregúntele a su médico} si el alcohol puede afectar la medicina que usted está tomando!

\section{JUGO DE TORONJA}

El jugo de toronja aumenta el efecto de ciertas medicinas. No tome jugo de toronja con su medicina.

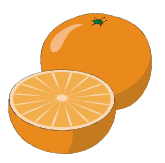

Si toma jugo de toronja, hágalo dos horas antes o después de tomar su medicina.

\section{LECHE}

Algunos antibióticos, como la tetraciclina, no deben tomarse con leche.

\section{VEGETALES}

Los vegetales ricos en vitamina $\mathrm{K}$,

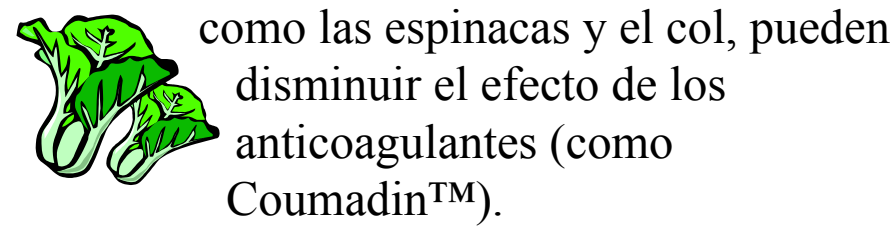

\section{R TÓMESE CON LOS ALIMENTOS}

Algunas medicinas deben tomarse conjuntamente con los alimentos. Esto puede ayudar a prevenir irritación en el estómago. Ejemplos de estas medicinas son el ibuprofén $\left(\right.$ como Motrin ${ }^{\mathrm{TM}}$ ) y ciertos diuréticos (como Aldactone $^{\mathrm{TM}}$ ).

Pídale más información a su médico o farmacéutico.

1. This is document FCS 8622-SPAN, one in a series of the Department of Family, Youth and Community Sciences, Florida Cooperative Extension Service, Institute of Food and Agricultural Sciences, University of Florida, Gainesville, FL 32611. Publication date: March 2004. The English version of this Spanish language leaflet is Healthy Living for Elders: Food Can Affect Your Medicines. This leaflet was developed with funding from the Florida Department of Elder Affairs in partnership with state, county, and local agencies. Please visit the EDIS Web site at http://edis.ifas.ufl.edu.

2. Paulina Wittkowsky, MS, RD, former education assistant, Department of Family, Youth and Community Sciences, Institute of Food and Agricultural Sciences, University of Florida, Gainesville, FL 32611. English version reviewed by Linda B. Bobroff, PhD, RD, LD/N, professor, University of Florida. Translation reviewed by Isabel ValentínOquendo, MS, RD, former FNP curriculum coordinator, University of Florida. 